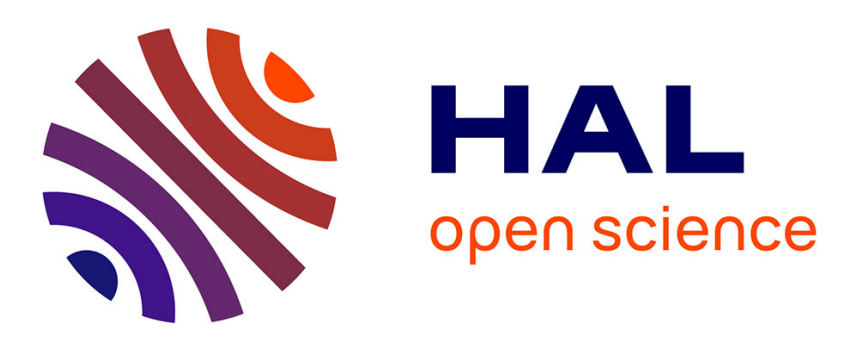

\title{
Mise en évidence de fortes circulations verticales temporaires entre zones humides et aquifères alluviaux et régionaux
}

Philippe Weng, Anne Coudrain-Ribstein, Cyril Kao, Hocine Bendjoudi, Ghislain De Marsily

\section{To cite this version:}

Philippe Weng, Anne Coudrain-Ribstein, Cyril Kao, Hocine Bendjoudi, Ghislain De Marsily. Mise en évidence de fortes circulations verticales temporaires entre zones humides et aquifères alluviaux et régionaux. Comptes rendus de l'Académie des sciences. Série IIa, Sciences de la terre et des planètes, 1999, 329 (4), pp.257-263. 10.1016/S1251-8050(99)80244-4 . ird-01230632

\section{HAL Id: ird-01230632 \\ https://hal.ird.fr/ird-01230632}

Submitted on 18 Nov 2015

HAL is a multi-disciplinary open access archive for the deposit and dissemination of scientific research documents, whether they are published or not. The documents may come from teaching and research institutions in France or abroad, or from public or private research centers.
L'archive ouverte pluridisciplinaire HAL, est destinée au dépôt et à la diffusion de documents scientifiques de niveau recherche, publiés ou non, émanant des établissements d'enseignement et de recherche français ou étrangers, des laboratoires publics ou privés. 


\title{
Mise en évidence de fortes circulations verticales temporaires entre zones humides et aquifères alluviaux et régionaux
}

\author{
Demonstration of strong temporary vertical circulation between wetlands and \\ alluvial and regional aquifers
}

\author{
Philippe Weng ${ }^{a}$, Anne Coudrain-Ribstein ${ }^{a}$, Cyril Kao ${ }^{b}$, Hocine Bendjoudi $^{a}$, Ghislain de Marsily \\ a UMR Sisyphe CNRS-UPMC, case 123, 4, place Jussieu, 75252 Paris cedex 05, France \\ b Cemagref, URE Ouvrages pour le drainage et l'étanchéité, BP 44, 92163 Antony cedex, France
}

(Reçu le 10 mars 1999, accepté après révision le 22 juin 1999)

\begin{abstract}
Tensiometric and piezometric values were recorded in an alluvial valley of the Seine wetland from February to November 1998. As a consequence of two flood events, the groundwater head once rose above the soil surface. When the water level in the Seine decreased, the vertical hydraulic gradient between the underlying Senonian chalk and the alluvia increased to 16\%0. During the few days of recession the alluvial wetlands were fed by an upward flow from the regional chalk aquifer and drained towards the river through a more permeable alluvial layer $(1.5 \mathrm{~m}$ to $7 \mathrm{~m}$ below soil surface). (@) Académie des sciences / Elsevier, Paris.)
\end{abstract}

hydrology / alluvial wetlands / piezometry / tensiometry / hydraulic head / hydraulic conductivity / Seine river / France

Résumé - Des mesures tensiométriques et piézométriques ont été effectuées de février à novembre 1998 sur une zone humide alluviale riveraine de la Seine moyenne. Pendant deux épisodes de crue, le niveau piézométrique a augmenté, jusqu'à dépasser la cote du sol pour l'un d'eux. En décrue, le gradient vertical de charge hydraulique entre la craie sous-jacente et les alluvions augmente jusqu'à des valeurs de $16 \%$. Les alluvions et les zones humides associées sont ainsi alimentées per ascensum et drainées vers la rivière par un niveau perméable situé entre 1,5 $\mathrm{m}$ et $7 \mathrm{~m}$ de profondeur. (C Académie des sciences/Elsevier, Paris.)

hydrologie / zones humides / piézométrie / tensiométrie / charge hydraulique / conductivité hydraulique / Seine / France

\section{Abridged version}

\section{Introduction}

Wetlands have the capacity to retain suspended particles, to eliminate some nutrients and some micropollutants and are ecologically important for their fauna and flora. Numerous ecological and biogeochemical studies of wetlands have been undertaken (Mitsch and Gosselink, 1986; Hook et al., 1988). To understand the biogeochemical processes of wetlands, the hydrology that defines the origin and dynamics of the water is also necessary, and is still today the lesser known aspect of their functioning. Various aspects of wetland hydrology have been studied previously (Gerla and Matheney, 1996; Hunt

\section{Note présentée par Ghislain de Marsily.}

* Correspondance et tirés à part.

weng@biogeodis.jussieu.fr 
et al., 1996; Cherkauer and Carlson, 1997; Hayashi et al., 1998; Schanen et al,, 1998). The aim of the present study is to characterize hydraulic circulation not only locally (metric scale) but also between a wetland meadow and its surroundings (kilometric scale). Regional hydrological studies have been made in tropical areas where the links between wetlands and the underground are limited to one direction: infiltration from the wetlands into the soil (Thompson and Hollis, 1995). In the studied region in a temperate zone, an inter-annual mean of the annual water balance was established on the regional scale (Weng et al., 1999) taking into account underground flows. It showed that around $400 \mathrm{Mm}^{3} \cdot \mathrm{yr}^{-1}$ of water flows from the underlying chalk aquifer to the alluvia and its associated wetlands and finally, into the Seine river. However, modelling of nitrate transfer (Greiner, 1997; Fustec et al., 1998) shows that this schematic scenario may include very different or even opposing situations that are very important for the understanding of water quality processes. To obtain a description of the flows on a more precise time and space scale, an experimental site was set up at the beginning of 1998 .

\section{Experimental site}

The experimental site is a regularly flooded wetland meadow close to the confluence of the Aube and the Seine rivers (figure 1). These wetiands are considered to be of major importance by the French Department of the Environment (Fustec et al., 1998). The soil is structured into three main layers: (i) from the soil surface to a depth of $45 \mathrm{~cm}$, muddy brown clay; (ii) from $45 \mathrm{~cm}$ to $120 \mathrm{~cm}$, muddy grey-green clay with some iron oxides; (iii) below this, first fine-grained alluvia and then coarse alluvia down to a depth of $7 \mathrm{~m}$. In summer, the alluvial water-table is approximately at $1.30 \mathrm{~m}$ under the soil surface. During flood events, the water-table may reach a level of $0.40 \mathrm{~m}$ above the soil surface. These Quaternary alluvia rest on the chalk that outcrops on hillsides on both sides of the alluvial plain. The chalk is about $350 \mathrm{~m}$ thick and contains an aquifer productive mainly over the first $50 \mathrm{~m}$ (Mégnien, 1979). These two aquifers are hydraulically connected.

To study the unsaturated zone, an experimental site was set up with two series of 10 tensiometric canes, sunk to depths between $20 \mathrm{~cm}$ and $2 \mathrm{~m}$. Tensiometric measurements were made with the help of a portable pressure collector SMS2500S (SDEC, France). They were made three times a day during flood periods and once a week during the other periods. For the saturated zone, two piezometers were drilled in the meadow. One is $15 \mathrm{~m}$ deep and reaches the chalk. The other, $6 \mathrm{~m}$ deep, penetrates only into the alluvia. Only the last $15 \mathrm{~cm}$ were screened to allow measurements of piezometric heads in the chalk and the alluvia. From February to May 1998, point measurements were made with a piezometric probe. From May to December 1998, automatic measurements of pressure were made every hour by DIVER DI105 collectors. The influence of the atmospheric pressure was taken into account by a third collector situated outside the wells. Within a radius of about $500 \mathrm{~m}$ around the experimental site, four other wells are available (Greiner, 1997). They are $5 \mathrm{~m}$ deep and totally screened. The last part of the equipment is a square vat of $7 \mathrm{~m}$, limited by plates of polycarbonate driven $60 \mathrm{~cm}$ into the ground. By measuring the water level inside and outside the vat, it is possible to identify either a submersion by surface flow or flooding by the rise of the groundwater level. The level of the Seine is measured $1 \mathrm{~km}$ downstream and upstream of the site.

\section{Results and discussion}

Measurements of the piezometric head in the wells drilled into the alluvia around the site show horizontal hydraulic gradient values ranging from $0.2 \% 0$ to $1 \%$ from southeast to northwest during most of the year. According to the mean annual water balance, the alluvial aquifer is drained by the Seine river (figure 1). During the observed flood events, in May and November 1998, the direction of flows in the alluvia changed and became northeast to southwest, with a hydraulic gradient of $0.4 \%$. In connection with the May flood the phreatic level rose above the soil surface. The site was covered by a $30-\mathrm{cm}$-thick sheet of water. During the November flood event, the site was not flooded but the water table rose to $30 \mathrm{~cm}$ under the soil surface. Figure 2 shows the evolution of the Seine river levels and the values of the vertical hydraulic gradient between the aquifers. It is clear that this vertical gradient presents its weakest values ( 0 to $1 \%$ ) during the maximum levels of the Seine river and that it increases rapidly when the water level decreases in the river. It reached values of $16 \%$ and $7 \%$ for the May and November flood events, respectively. This demonstrates that strong temporary vertical flows from the chalk to the upper alluvial aquifer occur during a recession in the Seine.

In the unsaturated zone, three different situations were identified: winter type, summer type and rise-and-drop type. Figure 3 shows the profiles of hydraulic heads in the soil. The left-hand side of this figure shows the winter-type (March) and summer-type (September) situations. In winter, the hydraulic head decreases smoothly from $20 \mathrm{~cm}$ to $1.2 \mathrm{~m}$, the level of the water table: the flow direction in the unsaturated zone is downward. In summer, the water table is $1.30 \mathrm{~m}$ below the soil surface, evapotranspiration is high and flows in the upper $80 \mathrm{~cm}$ of the soil are upward. Below $80 \mathrm{~cm}$ the soil is not affected by evapotranspiration

The evolution of hydraulic heads in the soil during a water-level drop in the Seine is presented on the right of figure 3. The four curves show the important role played by a more permeable alluvial layer below $1.40 \mathrm{~m}$ depth. On the one hand, the hydraulic heads in the alluvia are weakest below $1.40 \mathrm{~m}$. On the other hand, the decrease of hydraulic heads between the 7 th and the 8 th of May is greater at $1.50 \mathrm{~m}$ (around $15 \mathrm{~cm}$ ) than in the upper part of the soil (around $5 \mathrm{~cm}$ ). These results indicate that the soil is mainly drained toward the river by the more permeable alluvial layer. Hydraulic heads in the soil, the infiltration rate of the water on the wetland and Darcy's law were used to calculate the vertical hydraulic conductivity of the soil. Values range between $8.8 \cdot 10^{-6} \mathrm{~m} \mathrm{~s}^{-1}$ and $11 \cdot 10^{-6} \mathrm{~m} \mathrm{~s}^{-1}$ for the upper $1.40 \mathrm{~m}$ of the soil. These values are rather high and in good agreement with the observation of rapid flooding by the rise of the groundwater level accompany- 
ing flood events in the river. Moreover, the high permeability and the high humidity due to the proximity of the water table may explain why no flooding due to rainfall has been recorded.

Piezometric and tensionmetric data associated to the regional water balance allow the schematic functioning of the alluvial aquifer to be presented. The alluvia $\left(840 \mathrm{~km}^{2}\right)$ are mainly fed through their horizontal boundaries with $400 \mathrm{Mm}^{3}$ originating from the underlying chalk aquifer and with $127 \mathrm{Mm}^{3}$ originating from the net infiltration of rain. Inside the alluvia the flow is mainly horizontal and the outflow process is toward the river through the very permeable layers of the alluvia lying below $1.5 \mathrm{~m}$ below soil surface. Figure 4 shows the functioning of the two aquifers during a rise-and-drop cycle. High permeability in the alluvia allows the hydraulic head in the alluvial aquifer to decrease rapidly after the level of the river has fallen. The lower permeability of the regional chalk aquifer causes a vertical difference of hydraulic heads and upward flows from chalk to alluvia.

\section{Conclusion}

The daily/hourly measurements within a radius of $2 \mathrm{~km}$ around a wetland meadow allowed us to describe horizontal and vertical flows. Generally the real situation corresponded to the inter-annual mean: water flows sub-horizontally from the underlying chalk to the alluvia and from the alluvia to the Seine. It has been demonstrated that flooding of a wet meadow in the studied area is not due to rainfall but to the rise of the water table. Moreover, after a flood event in the Seine, important temporary vertical flow occurs from the underlying chalk to the upper alluvia with hydraulic gradients as high as $16 \%$. A permeable alluvial layer drains both the soil (downward flow) and the deeper chalk aquifer (upward flow). Thus, water circulation between the alluvia and the chalk is closely linked to the variations of the Seine levels. Therefore, the management of the river levels has a direct impact on the exchanges between all the water reservoirs and, as a consequence, on the chemical quality of the water.

\section{Introduction}

Les fonctions reconnues aux zones humides (rétention des matières en suspension, élimination de nutriments et de certains micropolluants, amortissement des crues, soutien des étiages et réserves en eau) ont, dans un premier temps, motivé de nombreuses études dans le domaine de la biogéochimie et de l'écologie (Mitsch et Gosselink, 1986 ; Hook et al., 1988). Plus récemment, les études ont porté sur les circulations d'eau entre les zones humides et les différents compartiments adjacents. Ainsi, Hayashi et al. (1998) ont quantifié les relations hydrologiques entre une mare et la dépression l'entourant, en vue d'établir un modèle conceptuel du fonctionnement de cette zone humide. Cherkauer et Carlson (1997) se sont intéressés aux relations entre un lac et l'aquifère sous-jacent. Gerla et Matheney (1996) ont étudié et modélisé en une dimension les transferts d'eau entre une prairie humide et le sous-sol. L'étude des circulations d'eau dans une zone humide a été abordée par des méthodes utilisant les isotopes stables, des profils de température et la modélisation mathématique (Hunt et al., 1996). Elle a aussi été menée à l'aide de méthodes d'optimisation (Schanen et al., 1998). Des études hydrologiques régionales ont été menées en milieu tropical, où les liens entre zones humides et sous-sol sont limités au flux d'infiltration depuis les zones humides vers le souterrain (Thompson et Hollis, 1995). La présente étude a pour objectif de caractériser les circulations hydriques entre le sol d'une prairie humide, les aquifères sousjacents (jusqu'à $15 \mathrm{~m}$ de profondeur) et la rivière, distante de $500 \mathrm{~m}$, dont le débit est contrôlé par l'action de l'Homme.

\section{Description et équipement du site expérimental}

La zone d'étude est située dans la plaine de Romilly-surSeine, à $100 \mathrm{~km}$ en amont de Paris, sélectionnée comme d'importance majeure par le ministère français de l'Environnement pour la mise en place d'un observatoire national des zones humides (Fustec et al., 1998). Un bilan hydrologique moyen interannuel a été mené sur la portion du bassin versant amont de la Seine, sur la craie du Crétacé supérieur $\left(2840 \mathrm{~km}^{2}\right)$. Il a montré qu'un flux d'eau de $400 \mathrm{Mm}^{3} \cdot \mathrm{an}^{-1}$ passe de l'aquifère de la craie vers les alluvions, elles-mêmes drainées par la Seine (Weng et al., 1999). La modélisation du transfert de nitrates depuis 1950 sur la zone d'étude (Greiner, 1997 ; Fustec et al., 1998) montre que ce schéma de fonctionnement moyen et global intègre vraisemblablement des situations hydrauliques très différentes, voire inverses, et qu'il doit être complété par une étude des circulations transitoires. À cette fin, un site expérimental a été équipé au début de l'année 1998, pour permettre de répondre à la question suivante : à un instant donné, d'où vient l'eau d'une zone humide riveraine de la Seine (pluie, débordement de rivière, remontée de nappe) et quelle est la dynamique associée à ces différentes sources?

Le site expérimental étudié et instrumenté est une prairie humide riveraine de la Seine, régulièrement inondée, à la confluence des rivières Aube et Seine (figure 1). Le sol est organisé en trois principaux horizons : (i) de la surface à $45 \mathrm{~cm}$, un horizon constitué d'argiles limoneuses de couleur brune ; (ii) entre 45 et $120 \mathrm{~cm}$, un horizon d'argiles limoneuses gris-vert, avec traces d'oxydes de fer ; 




Figure 1. Localisation du site expérimental et points d'observation (coupe et plan).

Location of the experimental site and observation network (cross-section and map).

(iii) de $120 \mathrm{~cm}$ à $7 \mathrm{~m}$, des alluvions fines à grossières. Ces alluvions quaternaires contiennent une nappe libre et reposent sur la craie qui affleure sur les coteaux, de part et d'autre de la plaine alluviale. La craie, dont la puissance est ici de $350 \mathrm{~m}$, est un aquifère productif sur les $50 \mathrm{~m}$ supérieurs (Mégnien, 1979). À l'étiage, la surface libre de la nappe des alluvions est située à environ $1,30 \mathrm{~m}$ sous le niveau du sol. Avec un battement saisonnier de la nappe de l'ordre de $1,70 \mathrm{~m}$, le niveau piézométrique est périodiquement au-dessus du niveau du sol.

L'équipement du site (figure 1) comprend, pour l'étude de la zone non saturée, deux séries de 10 cannes tensiométriques, enfoncées à des profondeurs allant de $20 \mathrm{~cm}$ à $2 \mathrm{~m}$. Les mesures tensiométriques sont faites à l'aide d'un capteur de pression portatif SMS2500S (SDEC France). Elles ont été effectuées trois fois par jour en période de crue et au pas de temps hebdomadaire pendant les autres périodes. Pour l'étude des niveaux saturés, deux piézomètres, situés sur la prairie, ont été équipés et crépinés sur les 15 derniers centimètres. L'un, profond de $15 \mathrm{~m}$, atteint la craie ; le second, profond de $6 \mathrm{~m}$, ne pénètre que dans les alluvions. Les charges dans la craie et dans les alluvions peuvent ainsi être mesurées séparément. Dans un premier temps, les mesures ont été effectuées ponctuellement à l'aide d'une sonde piézométrique, puis le site a été automatisé à partir de mai 1998 (capteurs de pression Diver DI105, mesures au pas de temps horaire). L'influence de la pression atmosphérique sur les mesures de piézométrie est prise en compte par un troisième capteur, placé à l'extérieur des piézomètres. Autour du site, à des distances d'environ $500 \mathrm{~m}$, quatre autres piézomètres de $5 \mathrm{~m}$ de profondeur, entièrement crépinés, permettent d'étudier les écoulements régionaux horizontaux. Une surface carrée de $7 \mathrm{~m}$ de côté a été isolée à l'aide de plaques de polycarbonate enfoncées à $60 \mathrm{~cm}$ dans le sol, scellées à l'aide de bentonite et jointes de manière étanche; elles ont une hauteur hors sol de $50 \mathrm{~cm}$. L'eau qui inonde la prairie par débordement de la rivière ne peut donc pas pénétrer directement dans ce bac. Dès la mise en eau de la prairie, les niveaux d'eau à l'intérieur et à l'extérieur du bac sont enregistrés avec un pas de temps de $5 \mathrm{~min}$. Des différences de niveaux d'eau entre l'intérieur et l'extérieur du bassin, qui seraient induites par un débordement de la rivière, peuvent ainsi être détectées avant le rééquilibrage des niveaux par des circulations souterraines contournant le bassin. Dans le cas d'une mise en eau par remontée phréatique uniquement, les niveaux d'eau intérieur et extérieur au bassin seront identiques durant toute l'inondation. De plus, un piézomètre de $1 \mathrm{~m}$ de profondeur est placé dans le bassin. Ce piézomètre est crépiné jusqu'à $10 \mathrm{~cm}$ sous la surface du sol et l'espace annulaire est scellé avec de la bentonite. II est équipé d'une canne ultrason et les enregistrements permettent de détecter s'il y a simultanéité entre la remontée de nappe et la présence 
de l'eau dans la zone humide. II est donc possible de séparer les contributions respectives de la remontée de nappe et de la submersion de la rivière lors d'une inondation. La cote de la Seine est mesurée à $1 \mathrm{~km}$ en aval et à l'amont du site (figure 1).

\section{Résultats et discussion}

Dans les alluvions de la prairie humide, durant la majeure partie de l'année et conformément au bilan moyen interannuel, les écoulements horizontaux ont une direction sud-est-nord-ouest (drainage par la Seine ; figure 1), avec des gradients hydrauliques de 0,2 à $1 \%$. En 1998, deux pics de crue ont êté enregistrés (figure 2), le premier en mai, le second en novembre. Durant la crue de mai, la prairie a été inondée par une lame d'eau de $30 \mathrm{~cm}$ d'épaisseur. Cette inondation est liée à une montée du niveau phréatique, comme l'attestent les variations synchrones des niveaux d'eau intérieur et extérieur du bassin. En novembre, le site $n^{\prime}$ a pas été inondé, mais le niveau phréatique est remonté jusqu'à $30 \mathrm{~cm}$ sous le niveau du sol. Lors des deux crues, les variations de la cote de la Seine et de niveau piézométrique sur le site ont été synchrones. Ainsi, les horizons supérieurs, bien qu'argilolimoneux, ne jouent pas, ici, de rôle imperméable pouvant rendre I'aquifère alluvial captif. Durant ces épisodes de crue, la direction des écoulements horizontaux est devenue nord-est-sud-ouest, avec un gradient hydraulique de $0,4 \%$. La composante verticale du gradient de charge (exprimée en \%) a été déterminée à l'aide des piézomètres du site (6 et $15 \mathrm{~m}$ de profondeur), selon l'équation suivante :

$$
i_{v}=|\overline{\operatorname{grad} H}|=\frac{H_{\text {craie }}-H_{\text {alluvions }}}{\Delta l} \times 1000
$$

où $\Delta I$, la différence d'altitude entre les crépines de chaque piézomètre est de $9 \mathrm{~m}$. Un gradient positif correspond à une circulation ascendante de la craie vers les alluvions. La précision des capteurs de pression étant de $0,5 \mathrm{~cm}$ de colonne d'eau, l'incertitude sur $i_{v}$ est de $\pm 1 \%$.

Hors période de crue, l'aquifère de la craie est toujours en charge par rapport à l'aquifère alluvial, avec un gradient de charge de 1 à $2 \%$ (figure 2 ). Au maximum de chaque crue, $i_{v}$ est inférieur à $2 \%$, ce qui indique que le flux ascendant est alors plus faible. Puis, lorsque le niveau de la Seine décroît, $i_{v}$ passe respectivement à des valeurs de 16 et $7 \%$ pour les décrues de mai et de novembre. Ceci démontre l'existence de flux ascendants importants, de la nappe de la craie vers la nappe alluviale, lors des décrues de la Seine.

L'étude des circulations dans la zone non saturée permet d'étudier l'évolution des charges hydrauliques sur les deux premiers mètres sous la surface du sol. La partie gauche de la figure 3 permet d'illustrer les circulations verticales dans la zone non saturée en hiver (mars) et en été (septembre). Durant la période hivernale, les circulations verticales sont globalement descendantes, comme I'atteste la répartition des charges hydrauliques $(68,75 \mathrm{~m}$ à $20 \mathrm{~cm} ; 68 \mathrm{~m}$ à 1,40 $\mathrm{m}$ de profondeur). L'eau du sol, ne participant pas à l'évapotranspiration, quasi nulle à cette période de l'année, se déplace par gravité vers la nappe située à 1,20 $\mathrm{m}$ de profondeur en mars. Durant la période estivale, où l'évapotranspiration est importante, le flux hydrique est ascendant dans la zone non saturée, avec une forte diminution de la charge hydraulique dans les 80
Figure 2. Évolution temporelle de la cote d'eau dans la Seine et du gradient vertical de charge hydraulique entre la nappe de la craie ( $15 \mathrm{~m}$ de profondeur) et la nappe alluviale $(6 \mathrm{~m}$ de profondeur). Un gradient positif signifie * flux ascendant .

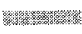

Temporary variations of the water level in the Seine river and the vertical hydraulic gradient between the chalk aquifer (at $15 \mathrm{~m}$ depth) and the alluvial aquifer (at $6 \mathrm{~m}$ depth). Positive gradient associated with upward flow.

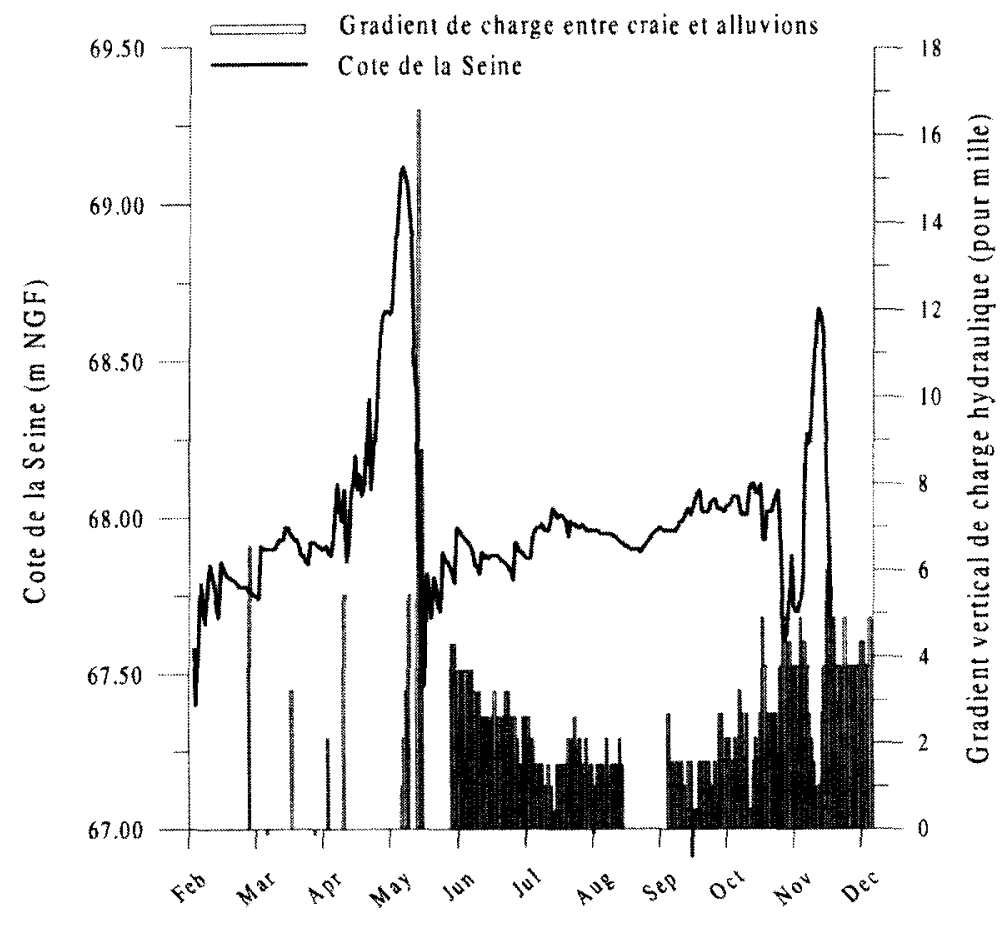



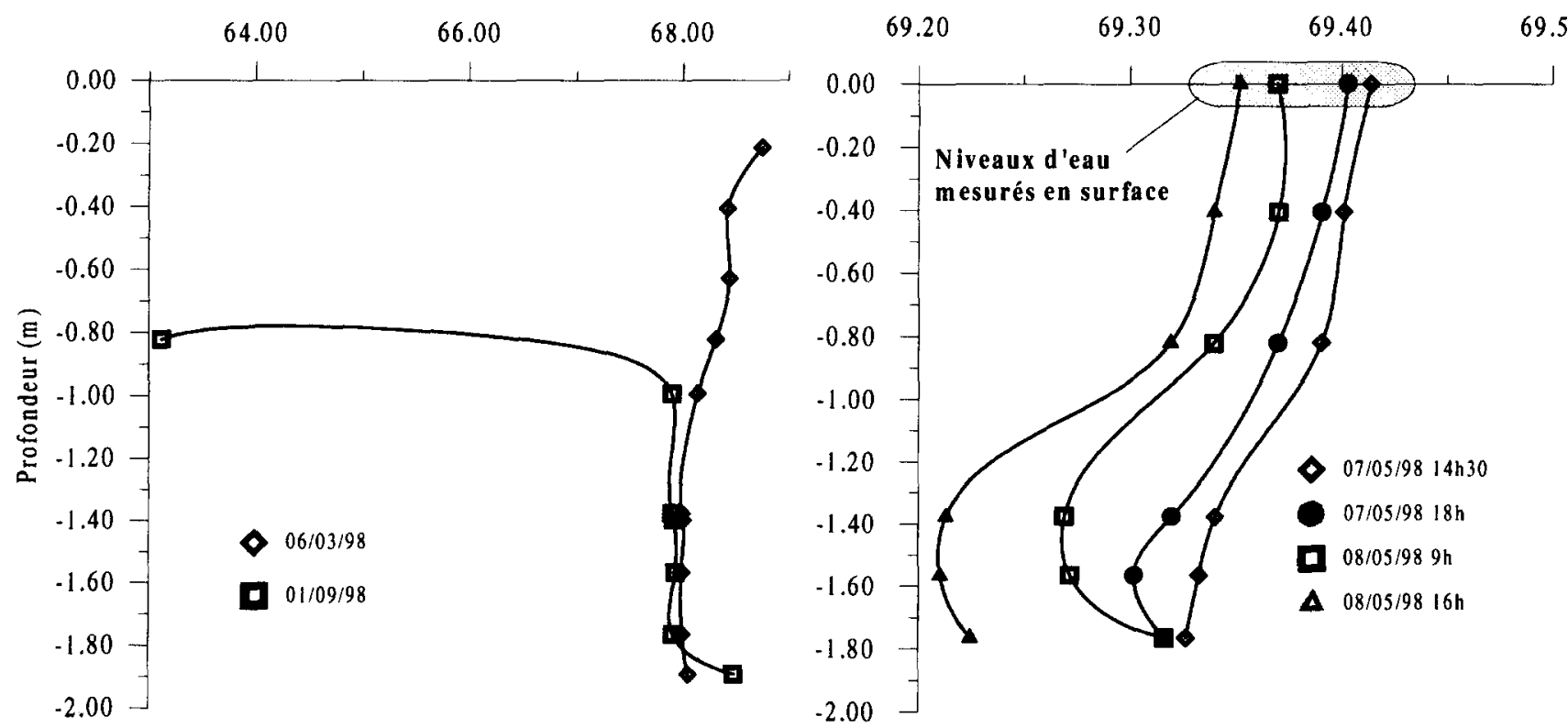

Figure 3. Profils de charges hydrauliques (obtenus par tensiométrie et par la cote de l'eau en surface) pour des situations classiques hivernales et estivales (à gauche; en été, les tensiomètres proches de la surface décrochent) et lors d'un suivi de décrue (à droite).

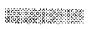

Hydraulic head profiles from tensiometric measurements and water level above soil surface for typical winter and summer situations (left; in summer the upper tensiometers are no longer operational) and during a water level drop (right).

premiers centimètres du sol, alors que le niveau de la nappe reste stable, à environ $1,3 \mathrm{~m}$ de profondeur.

Durant la période de décrue, les 7 et 8 mai 1998, la cote de l'eau sur la prairie inondée, ainsi que la tensiométrie, ont été mesurées plusieurs fois par jour (partie droite de la figure 3). L'analyse des différents profils permet de mettre en évidence le rôle de drain de l'horizon alluvial, à partir de 1,40 m de profondeur. Dans cet horizon, les charges hydrauliques présentent à la fois les valeurs les plus faibles et les variations temporelles les plus fortes de l'ensemble du profil au cours de la décrue. Connaissant la vitesse d'infiltration de l'eau sur la parcelle étudiée (grâce au carré de $7 \mathrm{~m}$ de côté), ainsi que la charge hydraulique à la surface du sol et à $1,4 \mathrm{~m}$ de profondeur, la loi de Darcy permet de calculer la conductivité hydraulique verticale à saturation $\left(K_{\text {sat }}\right)$ :

$$
|\vec{U}|=K_{\text {sat }}|\overrightarrow{\operatorname{grad} H}|
$$

avec $\vec{U}=$ vitesse de Darcy = vitesse d'infiltration de l'eau

$\overline{\text { grad } H}=$ gradient de charge calculé sur la base des mesures tensiométriques

$K_{\text {sat }}=$ conductivité hydraulique verticale à saturation moyenne sur $1,40 \mathrm{~m}$.

Les valeurs obtenues sont comprises entre $8,8 \cdot 10^{-6} \mathrm{~m} \cdot \mathrm{s}^{-1}$ et $11 \cdot 10^{-6} \mathrm{~m} \cdot \mathrm{s}^{-1}$. Elles corroborent l'un des résultats obtenu à l'aide de la piézométrie, à savoir que les horizons supérieurs ont une conductivité hydraulique re- lativement élevée et ne confèrent pas de caractère captif à la nappe sous-jacente. Ces horizons sont facilement traversés en période de crue et permettent des inondations par remontée phréatique. De plus, cette forte perméabilité et l'humidité importante due à la proximité de la nappe expliquent que, sur ce secteur, aucune inondation n'ait été enregistrée lors d'événements pluvieux importants.

Les données piézométriques et tensiométriques associées au bilan hydrologique régional permettent de dresser un schéma de fonctionnement hydrologique de la prairie alluviale. Les alluvions $\left(840 \mathrm{~km}^{2}\right)$ sont essentiellement alimentées à travers leurs limites horizontales par la craie sous-jacente $\left(400 \mathrm{Mm}^{3}\right)$ et par la pluie efficace $\left(127 \mathrm{Mm}^{3}\right)$. Le flux ascendant depuis la craie, déduit du bilan régional, est corroboré par l'observation locale du gradient hydraulique, qui est de l'ordre de $2 \%$ hors période crue et qui permet d'estimer une perméabilité verticale entre craie et alluvion de l'ordre de 5 à $15 \cdot 10^{-6} \mathrm{~m} \cdot \mathrm{s}^{-1}$. Ces flux entrant à travers les limites inférieures et supérieures des alluvions sont transmis par des circulations essentiellement horizontales (piézométrie et tensiométrie post-crue) vers la rivière, à travers des niveaux de très forte perméabilité, estimées à environ $10^{-2} \mathrm{~m} \cdot \mathrm{s}^{-1}$. La texture fine du sol permet le maintien d'une humidité proche de la saturation jusqu'à $80 \mathrm{~cm}$ de profondeur, même en été, lorsque le niveau saturé est à 1,3 m sous le sol. En période de crue, l'eau sature tout ou presque des horizons supérieurs. Lorsque le niveau de la Seine baisse, le drainage des premiers horizons fins du sol est assuré par les alluvions plus grossières en profondeur, 
où la charge hydraulique baisse rapidement (figure 4). La nappe de craie de plus faible perméabilité, et non connectée directement à la rivière, réagit moins rapidement aux variations de la cote de la rivière, ce qui engendre des différences de charge hydraulique entre ces deux nappes et la mise en place d'importantes circulations verticales ascendantes.

\section{Conclusion}

Le dispositif comprenant piézomètres, tensiomètres et bac en surface permet d'étudier les mécanismes de mise en eau des zones humides et, en particulier, de suivre des remontées phréatiques associées à des dynamiques de crue. L'utilisation conjointe du bassin et de la tensiométrie a permis d'effectuer des mesures de conductivité hydraulique in situ des premiers horizons de sol $\left(K \approx 10 \cdot 10^{-6} \mathrm{~m} \cdot \mathrm{s}^{-1}\right)$. Les circulations verticales ascendantes entre aquifère crayeux et aquifère alluvial sus-jacent sont attestées par des mesures de charge hydraulique dans ces deux aquifères. Si un flux ascendant existe toute l'année, il est cependant nettement supérieur (jusqu'à 10 fois) lors de variations importantes du niveau de la Seine. On peut dès lors déduire que la gestion anthropique de la cote de la Seine a une conséquence directe sur les circulations et donc sur la qualité chimique de la nappe alluviale. Rivières, zones humides, aquifère alluvial et aquifère régional sous-jacent sont de facto en continuité hydraulique, avec des caractéristiques hydrauliques notablement contrastées. En moyenne interannuelle, la topographie induit un flux moyen général de l'aquifère régio-

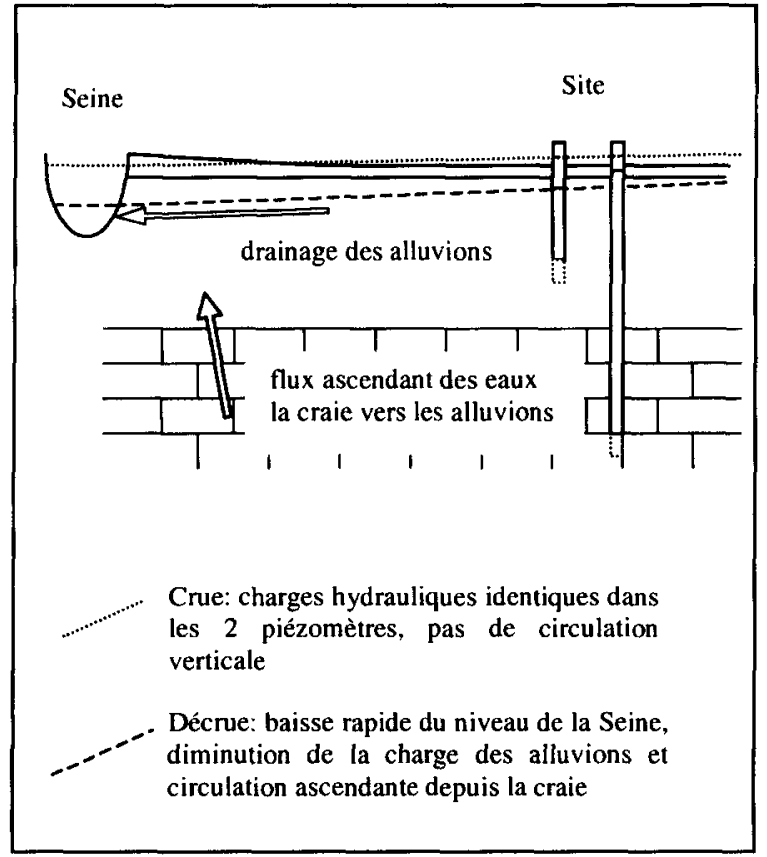

Figure 4. Comportement des différentes nappes lors d'une décrue de la Seine.

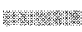

Behaviour of the different aquifers during a water level drop in the river.

nal crayeux affleurant sur les coteaux vers les alluvions sus-jacentes et drainées elles-mêmes par la rivière. Ce schéma moyen est bouleversé lorsque le niveau d'eau varie rapidement dans la rivière.

Remerciements. Ces travaux ont été effectués avec le soutien financier du Programme national de recherche sur les zones humides. Les auteurs remercient MM. C. Chaumont (Cemagref), B. Goetz. A. Ragu (UMR Sisyphe) et F. Giraud (BRGM) pour leur aide, ainsi que M. P. Ackerer pour ses critiques constructives.

\section{Références}

Cherkauer D.S. et Carison D.A. 1997. Interaction of lake Michigan with a layered aquifer stressed by drainage, Ground Water, 35 (6), 981-989

Fustec E., Greiner I., Schanen O., Gaillard S. et Dzana J.-G. 1998. Les zones humides riveraines : des milieux divers aux multiples fonctions, in : Meybeck M., Marsily G. de et Fustec E. (éds), La Seine en son bassin. Fonctionnement écologique d'un système fluvial anthropisé, Elsevier, Paris, 211-262

Gerla P.J. et Matheney R.K. 1996. Seasonal variability and simulation of ground-water flow in a prairie wetland, Hydrological processes, 10, 903-920

Greiner 1. 1997. Analyse de la variabilité fonctionnnelle de la plaine alluviale de la Seine et modélisation des transferts de nitrates, Thèse, Université Paris-6, Paris, 241 p.

Hayashi M., Kamp G. et Rudolph D.L. 1998. Water and solute transfer between a prairie wetland and adjacent uplands. 1. Water balance, J. Hydrol., 207, 42-55
Hook D.D. et al. (éds). 1988. The Ecology and management of Wetlands, 1, Croon Helm Timber Press, Portland

Hunt R.J., Krabbenhoft D.P. et Anderson M.P. 1996. Groundwater inflow measurements in wetland systems, Water Resour. Res., 32 (3), 495-507

Mégnien C. 1979. Hydrogéologie du centre du bassin parisien, BRGM, 98, $532 \mathrm{p}$.

Mitsch W.J. et Gosselink J. 1986. Wetlands, Van Nostrand Reinhold, New York

Schanen O., Bendjoudi H., Levassor A. et Fustec E. 1998. Quantification des écoulements nappe-gravières, en zone alluviale, par optimisation du bilan hydrologique, C. R. Acad. Sci. Paris, 326, série lla, 107-112

Thompson J. R. et Hollis G. E. 1995. Hydrological modelling and the sustainable development of the Hadejia-Nguru Wetlands, Nigeria, J. Sci. Hydrol., 40, 97-116

Weng P., Coudrain-Ribstein A., Talbi A. et Bendjoudi H. 1999. Groundwater circulations between alluvial aquifer and underlying Senonian chalk in the Seine valley, Phys. Chem. Earth, 24 (1-2), $151-154$ 